\title{
Ethical And Environmental Disclosures: An Analysis Of The Oil And Gas Industry
}

Violet C. Rogers, Stephen F. Austin State University, USA Jack R. Ethridge, Stephen F. Austin State University, USA Treba A. Marsh, Stephen F. Austin State University, USA Jessica Lott, Stephen F. Austin State University, USA

\begin{abstract}
This study investigates the similarities of ethical and environmental disclosures, as well as risk factors contained within annual reports for the reporting year 2009. The data were collected from Fortune 500 oil and gas company annual reports. Findings include: 1) an emphasis on environmental, financial, nonfinancial and ethical disclosures and 2) similar reported risks for all companies investigated. The findings illustrate that many of the studied oil and gas companies have similar disclosures but, on the other hand, are situation specific to particular company and location.
\end{abstract}

Keywords: Accounting Disclosures; Environmental and Ethical Disclosures; Oil and Gas Accounting

\section{INTRODUCTION}

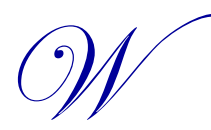

ithin the past decade, unethical financial and environmental behaviors of management and the overall company have become more frequently reported in the news. One would assume that additional disclosures of such concerns would be represented in annual reports. In today's highly political climate, it is essential that companies comply with a multitude of regulations concerning social and environmental responsibility. Consequentially, more laws have been enacted impacting oil and gas companies, thus increasing the number of explanations in annual reports. Laws that govern oil and gas companies are constantly changing, including accounting reporting standards. New regulations may highlight the need to report (or accrue) potential liabilities. Additionally, costs are incurred to establish and maintain new infrastructure needed to comply with new laws. The liabilities created by new regulations and public expectation of oil and gas companies have brought about the need for disclosures of such liabilities in annual reports.

This paper reports on ethical and environmental disclosures conveyed within oil and gas companies' annual reports. The paper also reports on risk factors for the industry. Research indicates more emphasis is being placed on environmental disclosures as compared to ethical disclosures. In some instances, these two types of disclosures are one in the same, depending on how the disclosure is worded or in which context it is portrayed. Additionally, risk factors identified in analyzed annual reports were similar.

Certain classes of ethical and environmental factors were noticed as being frequently emphasized. Examples include adopting a code of ethics, reducing future environmental liability, and improving assurance programs showing the commitment to minimizing environmental impact. Additionally, reporting risk factors has become more important, including topics ranging from potential losses from weather and climate changes and possibility of terrorist acts.

\section{Regulations}

Laws and regulations governing ethical and environmental disclosures illustrate a variety of content and format. Shareholder scrutiny increases the need for publicly traded companies' environmental disclosures, including understandable and non misleading footnotes. Currently, shareholders desire to see a real picture of appropriate disclosures regarding known and contingent liabilities (Wall, 2009). 
SEC rules (S-X) map out specific format and content of financial reports and \$210.4-10 prescribes financial accounting and reporting of oil and gas companies. This section defines terminology and proper reporting of particular aspects of each industry. Additionally, SEC rules (S-K) proscribe reporting requirements applicable to the content of the non-financial statement portions of various SEC filings used by public companies (SEC, 2009).

Under Regulation S-K, Item 101 requires description of business and risk factors and mandates disclosure of any actual or contingent material effects of compliance within environmental laws and regulations (SEC, 2007). Item 101(c) (1) (xii) specifically requires disclosure of the cost of complying with environmental laws:

Appropriate disclosure also shall be made as to the material effects that compliance with Federal, State and local provisions which have been enacted or adopted regulating the discharge of materials into the environment, or otherwise relating to the protection of the environment, may have upon the capital expenditures, earnings, and competitive position of the registrant and its subsidiaries. The registrant shall disclose any material estimated capital expenditures for environmental control facilities for the remainder of its current fiscal year and its succeeding fiscal year and for such further periods as the registrant may deem material (SEC, 2007).

For example, emphasis on climate change has dramatically increased. Climate change could be considered a result of a body of scientific evidence demonstrating that emissions of greenhouse gases, including carbon dioxide, are changing the world's climate with already extensive, and potentially catastrophic, effects (SEC, 2007). This change in climate poses major risks and opportunities for companies whose primary focus is the extraction and production of oil and natural gas (Young, 2009). Factors leading to this increase emphasis on climate change could be attributable to major hurricanes striking the Gulf of Mexico. Accordingly, extreme weather in the Gulf of Mexico has caused over $\$ 40$ billion in economic loss in recent years (Young, 2009).

Regulation S-K item 303 deals with Management's Discussion and Analysis (“MD\&A”) which requires discussion of known trends, events or uncertainties that may have a material effect on the company's financial condition. Some say this is the part of the annual report where an investor can view the company as from the eyes of management (Wall, 2009). Commission Staff has summarized the MD\&A requirement as follows:

Item 303 of Regulation $S$-K requires a company to discuss its financial condition, changes in financial condition and results of operations. A company must include in this section a discussion of its liquidity, capital resources, and results of operations. In particular, forward-looking information is required where there are known trends, uncertainties or other factors enumerated in the rules that will result in, or that are reasonably likely to result in, a material impact on the company's liquidity, capital resources, revenues and results of operations, including income from continuing operations. A company must focus on known material events and uncertainties that would cause reported financial information not to be necessarily indicative of future operating results or of future financial condition (SEC, 2007).

The section of Risk Factors for the oil and gas companies is defined by the SEC as, "This section should include a carefully organized series of short, concise sub-captioned paragraphs, with cross-references to fuller discussion where appropriate, summarizing the principal risk factors applicable to the offering and to the partnership's particular plan of operations. The risk factors section should be brief (SEC)."

What does this mean to the accounting profession? How are these topics addressed within annual reports? Accountants today must be aware of related accounting issues and be prepared to deal with social and/or environmental liabilities that companies incur. With the ever-changing regulations and disclosure requirements, accountants must be on their top game helping to portray the most realistic view of these companies within their annual reports. Auditors must also understand entity environment and related risk.

This paper reports on observations of ethical and environmental reporting for major United States oil and gas companies in 2009. In addition, a discussion of the risk factor section of the annual reports is included. This paper expresses that all companies contain ethical and environmental statements within disclosures. An example of these disclosures include continued focus on reducing future environmental liability by maintaining appropriate company standards and improving assurance programs showing the commitment to minimizing environmental impact. Thirty percent of the companies researched had a statement similar to this. 
Some researched companies reported impacts such as: "New regulations negatively impact financials." Some others do not predict the upcoming regulations and compliance cost to be material. All companies researched did predict that the number of such laws would increase. One mentioned that it would be difficult to predict overall cost of complying with new regulations.

\section{DATA COLLECTION}

The oil and gas industry was chosen for this study based upon discussions with practicing accountants. Accountants indicated that the oil and gas industry would be more likely than others to exhibit changes in environmental reporting and an increasing rate of environmental statements required. Additionally, the industry has experienced highly scrutinized ethical and environmental accidents in recent years.

The companies that were researched are Baker Hughes Incorporated, Chevron, El Paso Corporation, Frontier Oil Corporation, Halliburton, Hess Corporation, Holly Corporation, Kinder Morgan, Marathon, Murphy Oil, and Sunoco.

The graduate student and primary researchers made statement counts of financial ethical, financial environmental and risk factors collected from information included in Management Discussion and Analysis, President's Letter, and Other Discussion.

The reported disclosures indicated several interesting observations. One reported observation illustrated that $45 \%$ of companies researched stated, "Changes in environmental requirements are not suspected to have an impact on the overall consolidated statements." This disclosure is a combination of the following two statements: 1) "Changes in environmental requirements and/or failure to comply may negatively impact demand for our services", which was contained by $18 \%$ of the companies, and 2) "Compliance with environmental regulations will not have a material/adverse effect on capital expenditures", found in $27 \%$ of the oil and gas companies researched.

A relevant ethical statement purported the following: "Seasonal and adverse weather conditions adversely affect demand for our services and operations along with potential environmental fines and penalties. Examples include hurricanes and extreme winters, earthquakes, and tornadoes". Other specific statements contained information such as, "Hurricanes along the Gulf Coast could disrupt our supply of crude oil and our ability to complete capital investment projects in a timely manner."

\section{REPORTING YEAR}

A summary of ethical disclosures found within 2009 annual reports was constructed (see Appendix 1). Typically, annual reports illustrated specifics on how companies supported emphasis on health and safety, (a common disclosure observed throughout the research.) Furthermore, companies provided disclosures concerning impact on surrounding communities, various state and federal employment statues, adoption of the code of ethics, and many others. An example of an ethical statement taken out of one of the researched annual reports would be, "Devoted to improving the standards of living and well-being of people in surrounding communities."

A summary of environmental disclosures found within 2009 annual reports was also constructed (see Appendix 2). Typically, annual reports from this period discussed the increasing trend of environmental regulations and the impact the companies expected this change to have on the overall operations. Examples include current legislation, the rules and implications of the U. S. Environmental Protection Agency (EPA) and other regulatory agencies. One example of an environmental disclosure is "Company faces potential exposure from future claims and lawsuits involving environmental matters, including soil and water contamination, air pollution, personal injury, and property damage allegedly caused by substances that the company may have manufactured, handled, used, released, or deposed."

In addition, a summary chart was compiled for risk factors as well (see Appendix 3). This section is required by the SEC and enables a better picture of oil and gas companies for the benefit of investors. An example of a risk factor would be "Environmental risks - oil spills, gas leaks, and ruptures and discharges of substance or gases that could expose us to substantial liability for pollution or other environmental damage." 


\section{EXTENSIONS}

This paper serves as a starting point for future research. Of particular interest is comparing annual reports for 2009 with future annual reports to determine how new regulations and standards have affected the number and characteristics of environmental and ethical statements, as well as to see if the risk factors section will become more extensive as years go by and issuers find a higher need to see more deeply into these companies. Additionally, comparisons of ethical coverage across industries might also illustrate that certain ethical coverage is industryspecific.

\section{LIMITATIONS}

The research was exploratory in nature. As such, there was a strong possibility that data accumulation and construction were subjective. As annual reports were being read for the first and second time, there was a possibility that important items were overlooked and that unimportant items were emphasized. The extensive amount of environmental, ethical, and risk factor disclosures presented in these annual reports were classified into summarizations; therefore, there is room for various interpretations of the different statements and as to which summarized group best represented the statement.

To help control for such omissions and misinterpretation, a graduate student was employed to read the annual reports along with the primary researchers. Initially, the student marked all of the environmental, ethical, and relating risk factor disclosures and compiled a master list of environmental, ethical, and risk factor reporting topics and problems. The primary researchers then re-read the annual reports and added information. Research was limited to eleven companies due to the extensive size of these reports with repetitive data skewing our results.

\section{CONCLUSION}

It was interesting to note that companies are reporting new disclosures involving environmental issues such as climate change and political issues involving threats of terrorism. While new legislation has historically been addressed, the researchers noticed an increase in the discussion of possible effects.

\section{AUTHOR INFORMATION}

Violet C. Rogers, Ph.D., CPA is a Professor of Accountancy in the Gerald W. Schlief School of Accountancy at Stephen F. Austin State University in Nacogdoches TX. Her primary teaching interests include Oil and Gas Accounting, Auditing, and Managerial Accounting. Research interests include ethical and environmental disclosures and accounting for the oil and gas industry. Other interests include Auditing and audit changes as they relate to a changing environment. She served as Dean of the College of Business for six years before returning to full professor status three years ago. E-mail: vrogers@sfasu.edu (Corresponding author)

Jack R. Ethridge, Ph.D., CPA is a Professor of Accountancy in the Gerald W. Schlief School of Accountancy at Stephen F. Austin State University in Nacogdoches, TX. He holds the Temple Inland Employees Distinguished Professor of Accounting. His primary teaching interests include Accounting Theory, Advanced Accounting, Advanced Auditing and IFRS. Research interests include auditing, upcoming auditing changes as they relate to IFRS, accounting changes related to changing environments and accounting related disclosures. $\mathrm{He}$ served as Accounting Department Chair for many years before returning to full professor status. E-mail: jethridge@ @sasu.edu

Treba A. Marsh, DBA, CPA is Director of the Gerald W. Schlief School of Accountancy at Stephen F. Austin State University in Nacogdoches, TX. She holds full professor status. Her primary teaching interests include Intermediate Accounting, Governmental Accounting and Principles of Accounting. Research interests include ethical behaviors, governmental and financial accounting. She is active in state and national organizations and served as Beta Alpha Psi director for many years and holds a national position with Beta Alpha Psi. She is very active in recruiting students to our program and respective scholarship dollars. E-mail: tmarsh@sfasu.edu 
Jessica Lott, MPA, BBA, holds a Master of Professional Accountancy from Stephen F. Austin State University in Nacogdoches, TX. She participated in writing this research paper while she was a Master's student. Currently she resides in Houston and works in Public Accounting as an Auditor. E-mail: jessicalott@bellsouth.net

\section{REFERENCES}

1. Securities Exchange Commission, (2007). Petition for interpretive guidance on climate risk disclosure.

Retrieved from www.sec.gov/rules/petitions/2007/petn4-547.pdf

2. Securities Exchange Commission, (n.d.). Industry guides Retrieved from

www.sec.gov/about/forms/industryguides.pd

3. Securities Exchange Commission, Division of Corporate Finance. (2009). Rules, regulations, and schedules Retrieved from http://www.sec.gov/divisions/corpfin/ecfrlinks.shtml

4. Wall, M. (2009). Hot topics in environmental disclosure. American bar association section of environmental, energy, and resources, 17. Retrieved from www.winston.com/siteFiles/../ClimateRisk_ABA_MayWall.pdf

5. Young, Beth. (2009, June). Climate risk disclosure in SEC filings. Retrieved from www.edf.org/documents/9903_sec 12 web.pdf 


\section{APPENDIX 1}

Ethical Statement Disclosures in 2009 Annual Reports, $\mathbf{n = 1 1}$

\begin{tabular}{|l|l|}
\hline Company seeks to increase shareholder wealth and sustain profitable growth & $30 \%$ \\
\hline Most importantly, we focused on protecting and expanding our market share. & $9 \%$ \\
\hline Emphasizes employee safety and health & $64 \%$ \\
\hline $\begin{array}{l}\text { Supports education by working with local schools. Provides grants, funds national science programs, } \\
\text { scholarships. Supports math Olympiad, summer math programs, junior achievement, and 4-H. Provides } \\
\text { scholarships and grants. Funds computer labs. }\end{array}$ & $18 \%$ \\
\hline Devoted to improving the standards of living and well-being of people in surrounding communities. & $27 \%$ \\
\hline Subject to OSHA and comparable state occupation safety statues. & $55 \%$ \\
\hline $\begin{array}{l}\text { Required by SOX of 2002, have adopted a code of ethics that applies to our chief executive officer, chief } \\
\text { financial officer and principal accounting officer and employees on matters of business conduct and ethics, } \\
\text { including compliance standards and procedures. }\end{array}$ & $55 \%$ \\
\hline Stockholder return is a critical measure of our performance. & $9 \%$ \\
\hline $\begin{array}{l}\text { Includes pictures within annual reports to enhance the company's devotion to ethics. } \\
\text { Investigation by SEC of payments made to Government officials of foreign country.-Nothing was found } \\
\text { in investigation. }\end{array}$ & $9 \%$ \\
\hline $\begin{array}{l}\text { Tells the truth and respects others: Uphold high standards of business ethics and integrity enforce strict } \\
\text { principles of corporate governance, and support transparency in all operations. }\end{array}$ & $9 \%$ \\
\hline
\end{tabular}




\section{APPENDIX 2}

Environmental Statement Disclosures in 2009 Annual Reports, $\mathbf{n = 1 1}$

Subject to various governmental proceeding and regulations, including foreign regulations.

Commitment to Health and Safety of people, protection of environment, and compliance to laws, regulations, and company policies. Example: Special Programs

Reports that environmental expenditures are expensed or capitalized according to GAAP

Trend in environmental regulations is to place more stringent restrictions and limitations on activities and could require substantial expenditures.

Continue focus on reducing future environmental liability by maintaining appropriate company standards and improving assurance programs showing the commitment to minimizing environmental impact.

Changes in environmental requirements are not suspected to have an impact on the overall consolidated statements.

Noted actual losses from recent hurricanes in the Gulf that are still affecting the operations/financial statements of the company.

Recognizes climate change as a global environmental concern. Example: increases in insurance premiums and deductibles, decrease in available coverage in areas subject to severe weather.

Statements of remediation projects; companies are primarily responsible and these cost are accrued based on internal evaluation and are not discounted.

Noted that they received Notices of Violation from the EPA for various reasons.

Legislation to reduce greenhouse gas emissions are being proposed and promulgated.

Statements concerning climate change.

$65 \%$

$36 \%$

$36 \%$

$45 \%$

$27 \%$

$45 \%$

$36 \%$

$36 \%$

$63 \%$

$27 \%$

$67 \%$

$77 \%$ 


\section{APPENDIX 3}

Risk Factors Disclosed in 2009 Annual Reports, n=11

\begin{tabular}{|c|c|}
\hline Risk management activities may generate substantial losses and limit potential gains & $9 \%$ \\
\hline $\begin{array}{l}\text { Environmental risk that may require us to make substantial capital expenditures to remain in } \\
\text { compliance/comply to new standards or that could give rise to material liabilities. Or different } \\
\text { interpretations of existing laws }\end{array}$ & $55 \%$ \\
\hline $\begin{array}{l}\text { Impact of environmental and other regulations affecting the composition of gasoline and other refined } \\
\text { products. }\end{array}$ & $9 \%$ \\
\hline $\begin{array}{l}\text { Operations are subject to various laws and regulation relating to occupational health and safety, which } \\
\text { could give rise to increased costs and material liabilities }\end{array}$ & $27 \%$ \\
\hline $\begin{array}{l}\text { Incur substantial costs or disruptions in our business if we cannot obtain or maintain necessary permits } \\
\text { and authorizations }\end{array}$ & $9 \%$ \\
\hline $\begin{array}{l}\text { Hurricanes along the Gulf Coast could disrupt our supply or crude oil and our ability to complete capital } \\
\text { investment projects in a timely manner. }\end{array}$ & $9 \%$ \\
\hline We have labor relations difficulties with some of our employees represented by unions & $9 \%$ \\
\hline $\begin{array}{l}\text { Our business requires the retention and recruitment of a skilled workforce and the loss of employees could } \\
\text { result in the failure to implement our business plans }\end{array}$ & $9 \%$ \\
\hline Terrorist attacks and threats or actual war may negatively impact our business. & $55 \%$ \\
\hline $\begin{array}{l}\text { Seasonal and adverse weather conditions adversely affect demand for our services and operations along } \\
\text { with potential environmental fines and penalties. Examples include: Hurricanes and extreme winters, } \\
\text { earth quakes, tornados }\end{array}$ & $74 \%$ \\
\hline $\begin{array}{l}\text { Environmental risks- oil spills, gas leaks, and ruptures and discharges of substance or gases that could } \\
\text { expose us to substantial liability for pollution or other environmental damage. }\end{array}$ & $9 \%$ \\
\hline Competition & $18 \%$ \\
\hline External factors could influence operations. & $27 \%$ \\
\hline $\begin{array}{l}\text { Compliance with and changes in laws or adverse positions taken by taxing authorities could be costly and } \\
\text { could affect operating results. }\end{array}$ & $55 \%$ \\
\hline $\begin{array}{l}\text { Compliance with and rulings and litigation in connection with environmental regulations may adversely } \\
\text { affect our business and operating results. }\end{array}$ & $64 \%$ \\
\hline $\begin{array}{l}\text { Environmental compliance and remediation costs and the costs of environmental liabilities could exceed } \\
\text { our estimates }\end{array}$ & $9 \%$ \\
\hline Climate Change regulations could result in increased operating capital costs & $36 \%$ \\
\hline Foreign Corrupt Practices Act Investigations & $9 \%$ \\
\hline Geopolitical and International Environment & $18 \%$ \\
\hline $\begin{array}{l}\text { Factors affecting the price of oil and natural gas include global weather conditions and natural disasters, } \\
\text { worldwide political, military, and economic conditions. }\end{array}$ & $55 \%$ \\
\hline
\end{tabular}

